\title{
Electroencephalography: Experience at Abakaliki Nigeria
}

\author{
Chukwuemeka O Eze ${ }^{1}$, Olaronke F Afolabi ${ }^{1}$, Emeka O Onwe ${ }^{2}$, Richard L Ewah ${ }^{3}$, Ugochukwu U Nnadozie ${ }^{4}$, \\ Francis C Okoro ${ }^{1}$, Eugene $\mathrm{C} \mathrm{Nzei}^{1}$ \& Chiamaka Okereke ${ }^{5}$ \\ ${ }^{1}$ Internal Medicine Department, Alex Ekwueme Federal University Teaching Hospital, Abakaliki (AEFUTHA), \\ Ebonyi State, Nigeria \\ 2 Paediatrics Department, Alex Ekwueme Federal University Teaching Hospital, Abakaliki (AEFUTHA), Ebonyi \\ State, Nigeria \\ ${ }^{3}$ Anaesthesia Department, Alex Ekwueme Federal University Teaching Hospital, Abakaliki (AEFUTHA), Ebonyi \\ State, Nigeria \\ ${ }^{4}$ Surgery Department, Alex Ekwueme Federal University Teaching Hospital, Abakaliki (AEFUTHA), Ebonyi \\ State, Nigeria \\ ${ }^{5}$ Internal Medicine Department, University of Nigeria Teaching Hospital (UNTH), Enugu, Nigeria \\ Correspondence: Dr. Chukwuemeka O EZE, Internal Medicine Department, Alex Ekwueme Federal University \\ Teaching Hospital, Abakaliki (AEFUTHA), Ebonyi State, Nigeria. Tel: 234-703-343-2117.
}

Received: May 28, 2021 Accepted: July 11, 2021 Online Published: August 11, 2021

doi:10.5539/gjhs.v13n9p71 URL: https://doi.org/10.5539/gjhs.v13n9p71

\begin{abstract}
Background: Electroencephalography (EEG) remains the most important investigative modality in the evaluation of individuals with epilepsy and other neurological disorders. The pattern of EEG done in a tertiary hospital at Abakaliki Nigeria is not known. It is against this background that we embarked on this retrospective observational study on the EEG pattern and patient characteristics in Neurophysiology laboratory at Abakaliki Nigeria.
\end{abstract}

Method: This is a retrospective observational hospital based study where the attendance register of the Neurophysiology laboratory was used to extract information on the demography, clinical characteristics and EEG reports of patients seen at the Laboratory from November 2018 to April 2021.

Results: A total of 125 (Male- 69, Female- 56) persons did EEG over the study period, and $75.2 \%$ had epileptiform waves (generalized- $16.8 \%$, focal- $57.6 \%$ ).

Conclusion: EEG services are been utilized at Abakaliki in evaluation of seizure disorder and other paroxysmal neurological events with more prevalent focal epileptiform waves.

Keywords: electroencephalography, epileptiform waves, neurophysiology laboratory, Abakaliki, Nigeria

\section{Introduction}

Electroencephalograph (EEG) is a tool for recording spontaneous electrical activities generated in the cerebral cortex using multiple electrodes placed on the scalp (Paudel, Limbu, Panta, Ghimire, Shrestha, \& Deo, 2012). EEG signal is a reflection of electrical currents flowing in the extracellular space generated by the algebraic summation of excitatory (EPSP) and inhibitory postsynaptic potentials (IPSP) that occur on many cortical neurons (Paudel et al., 2012). The summated EPSP and IPSP are then conducted through the skull and picked up by electrodes placed on the scalp. One estimate suggests that $6 \mathrm{~cm}^{2}$ of cortical surface area must be synchronously activated for a potential to be recorded at the scalp (Paudel et al., 2012).

EEG remains the most important investigative modality in the diagnostic evaluation of individuals with epilepsy (Panayiotopoulos, Michael, Sanders, Valeta, \& Koutroumanidis, 2008). Although the diagnosis of epilepsy is essentially clinical, EEG is used to confirm the diagnosis, and characterize the seizure type. It is also used to differentiate epileptic seizures from other types of spells, and to differentiate "organic" encephalopathy from primary psychiatric syndromes such as catatonia. Other uses include as an adjunct test of brain death, to prognosticate, in certain instances, in patients with coma and to determine whether to wean anti-epileptic medications.

The duration of EEG recording varies among laboratories and several recommendations have been published. 
Craciun and colleagues in a review of 1,005 EEG recordings provided evidence for recommending at least 20 minutes recording duration for standard awake EEG and 30 minutes for sleep EEG in patients with epilepsy-related indications (Craciun, Gardella, Alving, Terney, Mindruta, Zarubova, \& Beniczky, 2014).

There has not been any study on the use of EEG at the Alex Ekwueme Federal University Teaching Hospital Abakaliki. It is against this background that we conducted the study on Experience of EEG use at the Alex Ekwueme Federal University Teaching Hospital Abakaliki. The findings in this study will constitute data base for future reference and for health planning purposes.

\section{Methodology}

This is a retrospective descriptive hospital based study undertaken at the Neurophysiology laboratory of the Alex Ekwueme Federal University Teaching Hospital Abakaliki, a tertiary hospital in Abakaliki Nigeria. The hospital is a referral hub for Ebonyi state, and the surrounding states. The laboratory attends to both pediatric and adult patients with referral from within and outside the hospital. The EEG tests were conducted by certified EEG technologists using Contec KT88-3200, a 32 Channel EEG Machine and the reports were done by Neurologists with special interest in Neurophysiology. The recordings lasted for 20-30 minutes and were obtained by placing electrodes on the scalp with a conductive gel. Prior to electrode placement, the scalp area was prepared by clean shaving and light abrasion of the skin to reduce impedance due to dead skin cells. Electrodes were applied on the scalp using the 10-20 system of electrode placement using electrode gel (Towle et al., 1993). The EEG register was used to extract data on demographic variables and results of the EEG tests done from November 2018 to April 2021. The data were analyzed with Statistical Package for the Social Sciences (SPSS) version 25. The categorical variables were presented as proportions and percentages while numerical variables were presented as means and standard deviations. Chi -square with Yates correction was used to test for statistical significance of categorical variables while $t$ - test for numerical variables and $p$-value of $<0.05$ as significant.

\section{Results}

A total of 125 patients had EEG done during the study period of 2.5 years. There were $69(55.2 \%)$ males and 56 (44.8\%) females. The mean age was $28.7 \pm 11.5$ years and $83(62.4 \%)$ persons were $<40$ years. The details of age and sex distribution are found in Table 1.

Table 1. Age and sex distribution

\begin{tabular}{lllc}
\hline Age range (years) & Male- n (\%) & Female- n (\%) & Total N (\%) \\
\hline $0-9$ & $6(4.8)$ & $3(2.4)$ & $9(7.2)$ \\
$10-19$ & $6(4.8)$ & $13(10.4)$ & $19(15.2)$ \\
$20-29$ & $25(20)$ & $14(11.2)$ & $39(31.2)$ \\
$30-39$ & $13(10.4)$ & $5(4.0)$ & $18(10.8)$ \\
$40-49$ & $4(3.2)$ & $10(8.0)$ & $14(11.2)$ \\
$50-59$ & $7(5.6)$ & $4(3.2)$ & $11(8.8)$ \\
$60-69$ & $6(4.8)$ & $2(1.6)$ & $8(6.4)$ \\
$70-79$ & $2(1.6)$ & $5(4.0)$ & $7(7.6)$ \\
Total & $\mathbf{6 9}(\mathbf{5 5 . 2})$ & $\mathbf{5 6}(\mathbf{4 4 . 8})$ & $\mathbf{1 2 5}(\mathbf{1 0 0})$ \\
\hline
\end{tabular}

Thirty one (24.8\%) persons had normal EEG tracings while 94 (75.2\%) had abnormal EEG studies. The abnormalities seen were focal epileptiform waves- 72 (57.6\%), generalized epileptiform waves- 21 (16.8), and diffused slow waves- $1(0.8 \%)$. Generalized epileptiform waves were seen more in young individuals without sex predilection while multifocal epileptiform waves were seen more in older folks. The details are found in Tables 2 and 3 .

The sources of patient referral were from Internal medicine department, Psychiatry, Pediatrics, Family medicine, and Peripheral hospitals in descending order of magnitude. The details are found in Table 4. 
Table 2. EEG findings

\begin{tabular}{llcccc}
\hline & Normal-n & $\begin{array}{c}\text { Diffused Slow } \\
\text { waves-n }\end{array}$ & $\begin{array}{c}\text { Focal Epileptiform } \\
\text { waves-n }\end{array}$ & $\begin{array}{c}\text { Generalized Epileptiform } \\
\text { waves-n }\end{array}$ & p-value \\
\hline Male & 16 & 1 & 42 & 10 & 0.7988 \\
Female & 15 & 0 & 30 & 11 & 0.9706 \\
\hline$<40 \mathrm{yrs}$ & 20 & 0 & 43 & 1 & 20 \\
$\geq 40 \mathrm{yrs}$ & 11 & 1 & 29 & 1 & \\
\hline
\end{tabular}

Table 3. Focal EEG abnormalities

\begin{tabular}{lcccc}
\hline Variables & Right focal-n & Left focal- $\mathbf{n}$ & Multifocal- $\mathbf{n}$ & p-value \\
\hline Male & 20 & 18 & 4 & 0.7367 \\
Female & 15 & 12 & 3 & 0.1728 \\
\hline$<40$ years & 22 & 19 & 2 & \\
$\geq 40$ years & 13 & 11 & 5 & \\
\hline
\end{tabular}

Table 4. Source of referral

\begin{tabular}{lc}
\hline Source of referral & $\mathbf{n}(\mathbf{\%})$ \\
\hline Internal medicine & $89(71.2)$ \\
Psychiatry & $17(13.6)$ \\
Pediatrics & $9(7.2)$ \\
Family medicine & $6(4.8)$ \\
Peripheral hospitals & $4(3.2)$ \\
Total & $125(100)$ \\
\hline
\end{tabular}

\section{Discussion}

This is the first hospital based study of EEG pattern in Abakaliki Nigeria. The total number of EEG done over the study period of 2.5 years was 125 and it is low compared to other hospital based studies in Nigeria which reported higher values (Lagunju et al., 2015; Ajiboye, Abiodun, \& Ogbebor, 2017; Owolabi et al., 2013; Salisu \& Senbanjo, 2019; Igwe et al., 2014). This could result from the fact that EEG services domiciled in Neurology unit became available in late 2018. Consequently, the clinicians and patients awareness level is still low. Also, there was significant interruption of the EEG and other clinical services at the study centre during the peak of first wave of Corona virus disease (COVID) 19 lockdown in 2020 (Afolabi et al., 2020).

The male preponderance recorded in this study is similar to the report of other hospital based studies in Nigeria (Lagunju et al., 2015; Ajiboye et al., 2017; Owolabi et al., 2013; Salisu \& Senbanjo, 2019; Igwe et al., 2014). The male preponderance sterns from higher prevalence and incidence of seizure in male folks due to their greater exposure to risk factors for symptomatic seizure (McHugh \& Delanty, 2008; Fiest et al., 2017). Also, the concealment of the condition in women for sociocultural reasons in certain places may contribute to male preponderance (Bharucha et al., 1988).

The mean age of the study population was 28.7 years and $62.4 \%$ were $<40$ years. The above findings show that the majority of the patients were young. This is similar to other studies in Nigeria (Lagunju et al., 2015; Ajiboye et al., 2017; L. F., Owolabi, Shehu, S. D., Owolabi, \& Umar, 2013; Salisu \& Senbanjo, 2019; Igwe et al., 2014). Although the prevalence of seizure is higher in extremes of ages (Fiest et al., 2017; Beghi \& Giussani, 2018), it peaks in children in low-middle income countries (LMIC) like Nigeria as a result of under-diagnosis of the condition in older individuals as well as the demographic structure of the country (Beghi \& Giussani, 2018). The above could explain the preponderance of young individuals in the study population.

About a quarter of the study population had normal EEG findings while about $75 \%$ had abnormal (epileptiform) waves. The presence of epileptiform waves in $75 \%$ of the cases was rather high as the test was done in awake state. 
Smith (2005) reported a sensitivity of first interictal EEG to be about 50\%, though Binnie (1996) noted that it can be increased to $80 \%$ by sleep deprivation.Lagunju et al. (2015) reported $87 \%$ interictalepileptiform waves in children while Owolabi et al. (2013) reported 57\% in adult population both in Nigerian population.The high sensitivity in this study could result from strict patient selection as most of the patients were referred from the neurology clinics. Also, the application of the standard activation procedures of hyperventilation (up to three minutes), photic stimulation, recording during eye closure and long recording duration could contribute to the high yield.

Majority of the patients with abnormal EEG findings had focal epileptiform discharges and it's similar to the studies in the United States (Zarrelli, Beghi, Rocca, \& Hauser, 1999; Scheffer et al., 2017). This is contrary to the findings of Lagunju et al. (2015) who reported preponderance of generalized epileptiform waves in children. The above findings could be as a result of majority of the study population been adults with higher risk of focal symptomatic and cryptogenic seizure (Zarrelli et al., 1999).

Multifocal IEDs were reported more in older folks in this study. This is expected as symptomatic seizures from stroke, meningoencephalitis and metabolic disorders are most prevalent cause of seizure disorder in elderly patients (Kaur et al., 2018).

Most of the patients were referred from Internal Medicine, Psychiatry, Paediatrics and Family Medicine in descending order. This is similar to the report of Ajiboye et al. (2017). These departments manage seizure disorder and other paroxysmal conditions in which EEG test may be indicated for their evaluation.

\section{Conclusion and Recommendations}

There is increasing awareness and utilization of EEG in patient evaluation at Abakaliki Nigeria with preponderance of male folks. The abnormalities noted were predominantly focal epileptiform discharges. Generalized epileptiform discharges were more seen in younger people in contrast to multifocal waves seen predominantly on the older age group.

There is a need for creation of more awareness on the availability of EEG services for more utilization. There is also a need to procure video EEG which will enhance the yield and also improve the accuracy of the EEG interpretations.

\section{Competing Interests Statement}

The authors declare that there are no competing or potential conflicts of interest.

\section{References}

Afolabi, O. F., Nwobodo, M. U., Eze, C. O., \& Nnadozie, U. U. (2020). Impact of COVID-19 Pandemic on Haemodialysis Care at a Tertiary Centre in South East Nigeria. Open Journal of Nephrology, 10, 383-387. https://doi.org/10.4236/ojneph.2020.104038

Ajiboye, P. O., Abiodun, O. A., \& Ogbebor, A. I. (2017). An investigation of the patterns and outcomes of Electroencephalographic (EEG) recording requests in the management of neuropsychiatric disorders in a teaching Hospital in Nigeria. African health sciences, 17(3), 852-858. https://doi.org/10.4314/ahs.v17i3.28

Beghi, E., \& Giussani, G. (2018). Aging and the Epidemiology of Epilepsy. Neuroepidemiology, 51, 216-223. https://doi.org/10.1159/000493484

Bharucha, N. E., Bharucha, E. P., Bharucha, A. E., Bhise, A. V., \& Schoenberg, B. S. (1988). Prevalence of epilepsy in the Parsi community of Bombay. Epilepsia, 29(2), 111-115. https://doi.org/10.1111/j.1528-1157.1988.tb04405.x

Binnie, C. D. (1996). Epilepsy in adults: diagnostic EEG investigation. In: J. Kimura, \& H. Shibasaki (Eds.), Recent advances in clinical neurophysiology (pp. 217-222). Amsterdam: Elsevier.

Craciun, L., Gardella, E., Alving, J., Terney, D., Mindruta, I., Zarubova, J., \& Beniczky, S. (2014). How long shall we record electroencephalography? Actaneurologica Scandinavica, 129(2), e9-e11. https://doi.org/10.1111/ane.12186

Fiest, K. M., Sauro, K. M., Wiebe, S., Patten, S. B., Kwon, C. S., Dykeman, J., .. \& \& Jetté, N. (2017). Prevalence and incidence of epilepsy: A systematic review and meta-analysis of international studies. Neurology, $88(3)$, 296-303. https://doi.org/10.1212/WNL.000000000003509

Igwe, S. C., Brigo, F., \& Beida, O. (2014). Patterns of diagnosis and therapeutic care of epilepsy at a tertiary referral center in Nigeria. Epilepsia, 55(3), 442-447. https://doi.org/10.1111/epi.12531 
Kaur, S., Garg, R., Aggarwal, S., Chawla, S., \& Pal, R. (2018). Adult onset seizures: Clinical, etiological, and radiological profile. Journal of family medicine and primary care, 7(1), 191-197. https://doi.org/10.4103/jfmpc.jfmpc_322_16

Lagunju, I. O., Oyinlade, A. O., Atalabi, O. M., Ogbole, G., Tedimola, O., Famosaya, A., ... \& Ragin, A. (2015). Electroencephalography as a tool for evidence-based diagnosis and improved outcomes in children with epilepsy in a resource-poor setting. Pan African Medical Journal, 22, 328 https://doi.org/10.11604/pamj.2015.22.328.7065

McHugh, J. C., \& Delanty, N. (2008). Epidemiology and classification of epilepsy: gender comparisons. International review of neurobiology, 83, 11-26. https://doi.org/10.1016/S0074-7742(08)00002-0

Owolabi, L. F., Shehu, S., Owolabi, S. D., \& Umar, M. (2013). Interictal electroencephalography in patients with epilepsy in northwestern Nigeria.Ann Nigerian Med, 7, 48-54. https://doi.org/10.4103/0331-3131.133096

Panayiotopoulos, C. P., Michael, M., Sanders, S., Valeta, T., \& Koutroumanidis, M. (2008). Benign childhood focal epilepsies: assessment of established and newly recognized syndromes. Brain: a journal of neurology, 131(Pt 9), 2264-2286. https://doi.org/10.1093/brain/awn162

Paudel, B. H., Limbu, N., Panta, R., Ghimire, N., Shrestha, B., \& Deo, San. (2012). Electroencephalography (EEG). Retrieved from https://www.researchgate.net/publication/316637387_Electroencephalography_EEG

Salisu, M. A., \& Senbanjo, I. O. (2019). Electroencephalographic profile of children attending a neurophysiology centre in Lagos, Nigeria. Clin. Invest. (Lond.), 9(3).

Scheffer, I. E., Berkovic, S., Capovilla, G., Connolly, M. B., French, J., Guilhoto, L., ... \& Zuberi, S. M. (2017). ILAE classification of the epilepsies: Position paper of the ILAE Commission for Classification and Terminology. Epilepsia, 58(4), 512-521. https://doi.org/10.1111/epi.13709

Smith, S. J. (2005). EEG in the diagnosis, classification, and management of patients with epilepsy. Journal of neurology, neurosurgery, and psychiatry, 76(Suppl 2), ii2-ii7. https://doi.org/10.1136/jnnp.2005.069245

Towle, V. L., Bolaños, J., Suarez, D., Tan, K., Grzeszczuk, R., Levin, D. N., Cakmur, R., Frank, S. A., \& Spire, J. P. (1993). The spatial location of EEG electrodes: locating the best-fitting sphere relative to cortical anatomy. $\begin{array}{llll}\text { Electroencephalography and clinical neurophysiology, } & 86(1), & 1-6 .\end{array}$ https://doi.org/10.1016/0013-4694(93)90061-y

Zarrelli, M. M., Beghi, E., Rocca, W. A., \& Hauser, W. A. (1999). Incidence of epileptic syndromes in Rochester, Minnesota: 1980-1984. Epilepsia, 40(12), 1708-1714. https://doi.org/10.1111/j.1528-1157.1999.tb01587.x

\section{Copyrights}

Copyright for this article is retained by the author(s), with first publication rights granted to the journal.

This is an open-access article distributed under the terms and conditions of the Creative Commons Attribution license (http://creativecommons.org/licenses/by/4.0/). 